\title{
Genotoxicity evaluation of balanced nutritional food for patients pasteurized by gamma irradiation at $4 \mathrm{kGy}$
}

\author{
Beom-Seok Song ${ }^{1 *}$, Jong-Heum Park ${ }^{1}$, Jae-Kyung Kim ${ }^{1}, \mathrm{Ha}^{-}$-Young Park ${ }^{1}$, \\ Dong-Ho Kim ${ }^{1}$, Seong-Gil Hong ${ }^{2}$, Sang-Hee Jeong ${ }^{3}$ \\ ${ }^{1}$ Department of Biotechnology, Advanced Radiation Technology Institute, Jeongeup 56212, Korea \\ ${ }^{2}$ Erom R\&D Center, Chuncheon 24427, Korea \\ ${ }^{3}$ Department of Biomedical Laboratory Science, Hoseo University, Asan 31499, Korea
}

\section{$4 \mathrm{kGy}$ 로 감마선 살균처리된 환자용 균형영양식의 유전독성 평가}

\author{
송범석 $^{1 *} \cdot$ 박종흠 $^{1} \cdot$ 김재경 $^{1} \cdot$ 박하영 $^{1} \cdot$ 김동호 $^{1} \cdot$ 홍성길 $^{2} \cdot$ 정상희 $^{3}$ \\ 1첨단방사선연구소 생명공학연구부, ${ }^{2}$ (주)이롬 생명과학연구원, ${ }^{3}$ 호서대학교 임상병리학과
}

\begin{abstract}
This study was conducted to evaluate the genotoxicity of balanced nutritional formular for patients containing various ingredients after gamma irradiation at $4 \mathrm{kGy}$. Since viable bacteria were not observed within the detection limit of $1 \mathrm{log} \mathrm{CFU} / \mathrm{g}$, a dose of $4 \mathrm{kGy}$ was appropriate for the pasteurization of the formular. In a bacterial reverse mutation assay, both hot water and methanol extracts of the formular exhibited dose-independent responses, which was similar to those obtained from that of the negative control (distilled water or dimethyl sulfoxide). In a chromosomal aberration test using lung fibroblast cells of Chinese hamster, the numbers of normal chromosomes were comparable to those observed in the negative control, regardless of the treatment dose and metabolic activation system. Furthermore, no significant increases in the frequency of micronucleated polychromatic erythrocytes were observed relative to the control, when mice were fed with the formular at doses up to $2,000 \mathrm{mg} / \mathrm{kg}$ body weight. Therefore, the balanced nutritional formular for patients did not exhibit genotoxicity when pasteurization by gamma irradiation at $4 \mathrm{kGy}$.
\end{abstract}

Key words : gamma irradiation, balanced nutritional food, genotoxicity

\section{서 론}

최근 삶의 질 향상과 더불어 환자용 균형영양식과 같은 특수용도식품의 소비가 증가하는 추세에 있다. 특수용도식 품의 국내 판매액은 2010년 2,925억 원에서 2015년 3,163억 원으로 매년 지속적으로 증가하고 있으며, 이중 환자용 균 형영양식은 전체 특수용도식품의 $9.65 \%$ 인 305억 원으로 집계되었다(1). 현재 판매되고 있는 환자용 균형영양식의 대부분은 캔에 포장된 액상 형태의 제품들이나, 제품의 부

*Corresponding author. E-mail : sbs0110@kaeri.re.kr Phone : 82-63-570-3211, Fax : 82-63-570-3207

Received 11 November 2016; Revised 26 December 2016; Accepted 26 December 2016.

Copyright (c) The Korean Society of Food Preservation. All rights reserved.
피와 중량에 따른 보관 및 휴대 편의성이 낮아 이를 개선할 수 있는 분말 형태 제품의 개발이 요구되고 있다.

분말 제품의 경우 수확된 농산물을 세척, 정선한 후 동결 건조, 열풍건조, 진공건조 등으로 건조 처리한 각각의 원료 들을 혼합하기 때문에 토양으로부터 유래하는 미생물들에 대한 오염 수준이 높으며 이를 제어하기 위한 살균처리 방법의 적용이 필요하다 $(2,3)$. 현재까지 분말 제품의 살균 처리 방법에는 훈증처리, 열풍처리, 조사처리 등이 있다. 훈증처리는 살균제를 연소시켜 가스형태로 일정 시간동안 식품을 처리하는 방법으로 살균제의 잔류로 인한 독성학적 위험성이 있으며, 훈증살균제 중 하나인 메틸브로마이드의 경우 오존층 파괴물질로 알려져 사용이 금지되어 있다(4). 또한 열풍처리는 열에 의해 살균하는 방법으로 분말 제품의 열화 현상으로 인한 맛의 변화가 발생한다는 단점이 있다 (5). 조사처리는 이온화 에너지의 미생물 DNA 손상을 통한 
살균효과를 이용하는 방법으로 비가열 살균법의 특성으로 열화에 의한 품질변화가 적고 투과력이 높아 포장된 제품의 살균처리가 가능하여 충전 과정중의 2차 오염에 대한 우려 가 없는 장점이 있다(6-8). 그러나 조사처리 식품의 안전성 에 대한 소비자의 인식 부재로 수용성이 낮다는 단점도 나타내고 있다(9).

조사처리 식품의 안전성 평가를 위해 1961년 'FAO/ $\mathrm{IAEA} / \mathrm{WHO}$ 공동 식품조사 건전성 평가 전문위원회(Joint Expert Committee on the Wholesomeness of Irradiated Food, JECFI')가 설립되어 1964년, 1969년 그리고 1976년 세 차례 의 국제회의를 소집하였으며, 1980 년도 이전까지 수행한 안전성 평가 연구들에 대한 검토를 통해 "어떠한 식품이든 $10 \mathrm{kGy}$ 이하의 선량으로 조사 처리된 식품은 독성학적, 영양학적 및 미생물학적 관점에서 어떠한 위험도 야기하지 않는다" 라는 결론을 내린 바 있다(10). 더 나아가 1997년도 에는 고선량 조사식품의 안전성에 관한 전문가 연구회의에 서 " $10 \mathrm{kGy}$ 보다 10배 이상 높은 선량에서도 건강상의 위험 이 없으며, 특히 과도하게 가열처리된 식품의 경우 식품으 로써 가치가 없는 것처럼 이온화 에너지도 과량 조사처리하 면 유해물질이 생성되기 이전에 관능적 품질이 변하므로 최대선량을 제한할 필요가 없다"고 발표하여 조사처리 식 품의 안전성을 다시 한 번 확인하였다(11). 이러한 국제적 안전성 검토 결과에도 불구하고 소비자 단체를 위주로 조사 처리 식품의 안전성에 대한 문제 제기가 일어나고 있으며, 해당 품목에 대한 실질적인 안전성 평가 자료를 요구하고 있다(12).

따라서, 본 연구에서는 환자용 균형영양식의 모델 식품 으로 제조한 분말 제품의 살균 방법으로 조사처리를 실시하 였으며, 독성학적 안전성 평가의 기초 자료로써 감마선 살 균처리한 환자용 균형영양식의 유전독성 여부를 확인하고 자 하였다.

\section{재료 및 방법}

\section{시료 준비 및 감마선 조사}

본 연구에서는 모델 식품으로 식품공전의 식품유형 중 환자용 균형영양식의 규격 기준에 부합하도록 분말 원료들 과 미네랄 및 비타민 분말이 혼합된 분말 조제품을 (주이롬 으로부터 공급받아 사용하였다(Table 1). 즉, 제품 1,000 $\mathrm{kcal}$ 당 단백질, 칼슘, 철, 아연, 비타민 $\mathrm{A}, \mathrm{B} 1, \mathrm{~B} 2, \mathrm{~B} 6, \mathrm{C}$, $\mathrm{D}, \mathrm{E}$, 나이아신 및 엽산 등이 일일 영양소 기준치의 $50 \%$ 이상 함유하도록 영양소를 강화하였으며, 예비실험을 통해 $10 \mathrm{kGy}$ 의 흡수선량으로 감마선 조사처리 시료의 영양성분 이 규격 기준 이상 함유하도록 첨가량을 조정하였다. 제조 된 최종 제품 $40 \mathrm{~g}$ 을 각각 $\mathrm{LDPE}$ (low density polyethylene) 포장지에 넣어 포장한 후 Co-60 감마선 조사시설(IR-70 gamma irradiator, MDS Nordian, Montreal, Canada)에서 2, 4, 6, 8 및 $10 \mathrm{kGy}$ 의 흡수선량(선량률 $10 \mathrm{kGy} / \mathrm{h}$ )이 되도록 $20^{\circ} \mathrm{C}$ 의 실온조건 하에서 감마선 조사처리하였다. 시료가 실제 흡수한 선량의 확인을 위해 alanine dosimeter(Bruker BioSpin GmbH, Rheinstetten, Germany)를 조사처리 전 포장 지에 부착하였으며, 조사처리 후 electron para-magnetic resonance analyzer(e-scan ${ }^{\mathrm{TM}}$ alanine dosimeter reader, Bruker $\mathrm{BioSpin} \mathrm{GmbH}$ )로 분석하였다. 이 dosimetry 시스템은 국제 원자력기구의 절차에 따라 표준화한 후 사용하였으며, 측 정된 흡수선량의 오차는 목표선량의 $5 \%$ 이내였다.

\section{생균수 측정}

감마선 흡수선량에 따른 시료의 총호기성세균, 효모 및 곰팡이, Bacillus cereus, Clostridium perfringens, 대장균군 생균수를 측정하였다. 즉, 시료 $10 \mathrm{~g}$ 에 대하여 멸균된 $0.1 \%$ 의 peptone수 $90 \mathrm{~g}$ 을 가하여 1 분간 Stomacher Lab Blender(Model 400, Tekmar Co., Cincinati, OH, USA)을 이 용하여 균질화한 후 10 진 희석법으로 희석하였다.

Table 1. Composition of the balanced nutritional formular

\begin{tabular}{lcc}
\hline \multicolumn{1}{c}{ Ingredients } & Weight $(\mathrm{g})$ & Ratio $(\%)$ \\
\hline Isolated soybean protein & 10.0 & 25.0 \\
Cereal powder & 7.0 & 17.5 \\
Vegetable protein mix & 5.0 & 12.5 \\
Brown rice powder & 4.0 & 10.0 \\
Palatinose & 4.0 & 10.0 \\
Soybean powder & 4.0 & 10.0 \\
Sweet pumpkin powder & 2.0 & 5.0 \\
Potato powder & 2.0 & 5.0 \\
Vitamin \& mineral mix & 1.3 & 3.3 \\
Brocoli powder & 0.2 & 0.5 \\
Black sesame powder & 0.2 & 0.5 \\
Cabbage powder & 0.2 & 0.5 \\
Salt & 0.1 & 0.2 \\
\hline
\end{tabular}

단계별로 희석된 시료 $100 \mu \mathrm{L}$ 를 각각의 배지에 도말하였 고 총호기성세균은 plate count agar(PCA, Difco Co., Detroit, MI, USA), 효모 및 곰팡이는 potato dextrose agar(PDA, Difco Co.), B. cereus는 mannitol egg yolk polymyxin agar(MYP, Difco Co.), Cl. perfringens 는 tryptose sulfite cycloserine agar(TSC, Oxoid, Basingstoke, England), 대장균 군은 $3 \mathrm{M}$ 건조필름 배지(3M Co., St. Paul, $\mathrm{MN}, \mathrm{USA})$ 를 사용하였다. 건조필름, $\mathrm{PCA}, \mathrm{MYP}$ 배지는 incubator (MIR-262, SANYO Electric Biomedical Co., Ltd., Ozu, Japan) 를 이용하여 $35^{\circ} \mathrm{C}$ 에서 $24-48$ 시간, $\mathrm{PDA}$ 배지는 $25^{\circ} \mathrm{C}$ 에서 
3-5일간 호기적 조건에서 배양하였으며, $\mathrm{TSC}$ 는 $\mathrm{CO}_{2}$ 발생 가스팩을 개봉하여 anaerobic $\operatorname{jar}\left(\mathrm{BD} \mathrm{GasPak}^{\mathrm{TM}} \mathrm{EZ}, \mathrm{BD}\right.$ Diagnostics, Saparks, $\mathrm{MD}$, USA)에 같이 넣어 미호기적 환경 을 조성한 후 $35^{\circ} \mathrm{C}$ 에서 48 시간 배양하였다. 각각의 배지에 서 집락을 계수하여 시료 $1 \mathrm{~g}$ 당 colony-forming unit(CFU)으 로 나타내었으며, 대장균군은 배양한 건조필름 배지에서 생성된 붉은 집락중 주위에 기포를 형성한 집락수를 계산하 였다. 미생물 검출을 위한 최소 한계치는 $101 \mathrm{CFU} / \mathrm{g}$ 이었다.

\section{복귀돌연변이원성 시험}

모델식품에 대한 복귀돌연변이원성 시험은 $\mathrm{OECD}$ guideline TG 471(13)에 따라 수행하였다. 시험에 사용된 균주는 Salmonella Typhimurium LT2를 친주로 하는 $S$. Typhimurium TA98, TA100, TA1535, TA1537로 국립보건 연구원(Osong, Korea)으로부터 분양받아 계대 보존하여 사 용하였다. 이들 균주는 사용에 앞서 histidine 요구성, crystal violet 감수성, ampicillin 내성, spontaneous 복귀변이 수 등 을 확인하였다. 시험물질 제조를 위해 열수 추출물은 시료 $10 \mathrm{~g}$ 에 물 $100 \mathrm{~mL}$ 을 넣어 $95^{\circ} \mathrm{C}$ 항온 수조에서 24 시간 동안 진탕 추출하였고 메탄올 추출물은 시료 $10 \mathrm{~g}$ 에 $95 \%$ 메탄올 $100 \mathrm{~mL}$ 를 넣어 실온 $\left(24^{\circ} \mathrm{C}\right)$ 항온수조에서 2 시간 동안 진탕 추출하였다. 각각의 추출물은 여과지(Whatman No. 2, Kent, $\mathrm{UK}$ )에 여과한 후 회전진공농축기(EYELA Co., Tokyo, Japan)로 24시간 건조하였다. 부형제로 열수 추출물은 멸균 증류수, 메탄올 추출물은 dimethyl sulfoxide(DMSO)를 사 용하였다. 예비실험을 통해 침전이 없고 세포독성을 나타 내지 않은 $5,000 \mathrm{\mu g} / \mathrm{plate}$ 를 최대 농도로 설정하였고 공비 2 로 희석하여 5 단계의 농도군을 설정하였다. 균주를 nutrient broth에 하룻밤 동안 배양하여 대수기 $\left(2 \times 10^{9}\right.$ cells $/ \mathrm{mL}$ ) 상태에 이르도록 한 다음 배양액 $0.1 \mathrm{~mL}$ 에 단계별 로 희석된 시험물질 $0.1 \mathrm{~mL}$ 을 첨가하였다. 대사활성계 적용 군에는 S9 mixture(20\%,v/v) $0.5 \mathrm{~mL}$ 을 첨가하였고 비적용 군에는 phosphate buffered saline(pH 7.4) $0.5 \mathrm{~mL}$ 을 혼합하 여 $37^{\circ} \mathrm{C}$ 에서 30 분간 pre-incubation 하였다. 이후 혼합된 시 료를 histidine/biotin을 함유한 top agar $2 \mathrm{~mL}$ 에 투입한 후 minimal glucose agar 배지에 부어 굳히고 $37^{\circ} \mathrm{C}$ 에서 48 시간 동안 배양하여 복귀돌연변이 집락을 계수하였다. 음성대조 물질로는 멸균 증류수 또는 $\mathrm{DMSO}$ 를, 양성대조물질로는 sodium azide(SA), 4-nitroquinoline $N$-oxide(4NQO), acridine mutagen ICR-191(ICR-191), benzopyrene(BP) 및 2aminoanthracene(2-AA) 등을 각 시험 균주의 특성에 맞추어 사용하였다.

\section{염색체 이상 시험}

환자용 균형영양식의 염색체 이상 시험은 $\mathrm{OECD}$ guideline TG 473(14)에 따라 Chinese hamster lung(CHL) fibroblast 세포주를 이용하여 실시하였다. 배지는 minimal essential medium에 fetal bovine serum(FBS)을 5\% 되도록 첨가하여 사용하였으며, 음성대조물질로는 시험물질의 용 매인 멸균 증류수와 $\mathrm{DMSO}$ 를, 양성대조물질로는 대사 활 성 조건하에서는 $\mathrm{BP}$ 를 $\mathrm{DMSO}$ 에 용해시켜 사용하였으며, 대사 활성 부재 하에서는 mitomycin C(MMC)를 멸균 증류 수에 용해시켜 사용하였다. 예비시험에서 실험물질을 처리 하여 세포증식 억제 여부를 관찰한 결과 최고농도를 5,000 $\mu \mathrm{g} / \mathrm{mL}$ 로 설정하였으며, 공비를 2 로 하여 5 단계 $(0,625$, $1,250,2,500,5,000 \mu \mathrm{g} / \mathrm{mL}$ )로 희석하여 본 실험을 실시하였 다. S9 mixture, 시험물질 및 양성대조물질이 포함된 배양액 으로 6 시간 배양한 다음 보통의 배양액으로 교환하여 16 시 간 동안 더 배양한 후 colcemid를 $0.2 \mu \mathrm{g} / \mathrm{mL}$ 이 되도록 처리 한 다음 2 시간 경과 후 $0.05 \%$ trypsin-ethylene diamine tetra-acetic acid를 첨가하여 원심분리 $(150 \times g, 5$ 분 $)$ 하였다. 상등액을 제거한 후 저장액 $(0.075 \mathrm{M} \mathrm{KCl}) 4 \mathrm{~mL}$ 로 현탁하고 $37^{\circ} \mathrm{C}$ 수조에서 20 분간 방치하였으며, 고정액(methanol: acetic acid=3:1, v/v)으로 3회 고정시킨 후 공기 건조법으로 슬라이드를 제조하여 $5 \% \mathrm{Giemsa}$ 로 30 분간 염색하였다. 제 작된 슬라이드는 광학현미경 하에서 1,000 배의 배율로 각 시험군당 100 개의 잘 퍼진 분열 중기 상에 대하여 동원체수 및 염색체 이상의 유무를 관찰하고, 이상의 종류와 수를 기록하였다.

\section{소핵시험}

실험동물은 ICR 마우스(수컷, 7주령)를 사용하여 온도 $22 \pm 3^{\circ} \mathrm{C}$, 상대습도 $50 \pm 20 \%$, 환기횟수 $10-15$ 회, 조명주기 12 시간, 조도 150-300 lux의 환경조건으로 설정된 호서대학교 안전성평가센터의 청정 동물 사육실에서 약 1 주일간의 순 화기간을 거친 후 $4 \mathrm{kGy}$ 로 감마선 조사처리한 환자용 균형 영양식을 경구 투여하였다. 예비시험으로 환자용 균형영양 식 분말을 멸균 증류수에 현탁하여 경구 투여가 가능한 최고 농도인 $2,000 \mathrm{mg} / \mathrm{kg}$ body weight를 투여하여 관찰한 결과 모든 동물에서 특별한 육안적 이상 소견이 관찰되지 않았다. 이에 $2,000 \mathrm{mg} / \mathrm{kg}$ 를 본 시험의 고용량으로 설정하 고, 공비를 2 로 하여 총 4 단계의 농도군 $(0,500,1,000,2,000$ $\mathrm{mg} / \mathrm{kg} \mathrm{bw}$ )에 대하여 각각 5 마리의 ICR 마우스에 주사기로 1 회 경구 투여하였다. 양성대조물질인 cyclophosphamide monohydrate(CPA)는 투여용량이 $80 \mathrm{mg} / \mathrm{kg} \mathrm{bw}$ 이 되도록 corn oil에 용해하여 마우스의 복강에 투여하였다. 시험물질

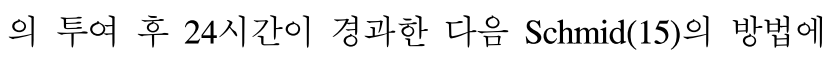
따라 골수 검체를 제작하였다. 즉, 마우스의 대퇴골에서 골수를 적출하여 FBS로 현탁하였다. 마우스당 2,000개의 다염성적혈구(polychromatic erythrocyte, $\mathrm{PCE}$ )를 관찰하여 그 중 소핵을 가진 다염성적혈구(micronucleated polychromatic erythrocyte, MNPCE)의 수를 계수하였다. 또한 총 적혈구 (PCE+normochromatic etythrocyte(NCE)) 중 $\mathrm{PCE}$ 값(PCE/ $(\mathrm{PCE}+\mathrm{NCE})$ )을 산출하여 세포독성 여부를 확인하였다. 본 
실험은 호서대학교 안전성평가센터의 동물실험윤리위원 회에 의해 승인을 받아 진행되었다(HTRC-15-01).

\section{통계처리}

모든 측정 결과는 평균값표준편차로 나타내었으며, Statistical Package for the Society Science(SPSS, windows ver 22.0, IBM, Armonk, NY, USA)을 이용하여 각 시료간의 유의성을 검증한 후 $\mathrm{p}<0.05$ 수준에서 Duncan's multiple range test로 사후검정을 실시하였다.

\section{결과 및 고 찰}

\section{모델식품의 미생물학적 오염도 평가 및 살균 선량 설정}

모델식품의 미생물학적 오염도와 흡수선량에 따른 생균 수 변화 측정 결과를 Table 2에 나타내었다. 비조사구의 경우 총 호기성세균과 진균류가 각각 $2.6,2.7 \log \mathrm{CFU} / \mathrm{g}$ 로 나타났고 B. cereus와 대장균군이 각각 2.5 와 $2.6 \log \mathrm{CFU} / \mathrm{g}$ 으로 검출되었다. 식품공전 중 모델식품의 제품유형인 환 자용 균형영양식의 미생물학적 기준은 총 호기성세균이 $10^{3} \mathrm{CFU} / \mathrm{g}$ 이하, B. cereus 가 $10^{2} \mathrm{CFU} / \mathrm{g}$ 이하, 대장균군이 음성이여야 한다. 따라서 모델식품의 경우 총호기성세균에 대한 규격을 만족하고 있으나, B. cereus에 대한 기준치 초 과와 대장균군의 검출로 인하여 추가적인 살균 공정이 필요 한 것으로 사료된다.

흡수선량에 따른 모델식품의 생균수 변화를 측정한 결 과, $2 \mathrm{kGy}$ 조사처리구에서 진균류를 제외한 나머지 시험항 목에 있어 모두 $1 \log \mathrm{CFU} / \mathrm{g}$ 의 검출한계 이하로 나타났고 $4 \mathrm{kGy}$ 이상의 흡수선량으로 감마선 조사처리 시 모든 항목 에서 검출한계 이하였다. $2 \mathrm{kGy}$ 조사처리구 역시 식품공전 의 미생물 규격 기준을 만족하고 있으나, 원재료 내 미생물 오염 수준의 변화에 대한 미생물학적 안전성을 확보하기 위하여 $4 \mathrm{kGy}$ 의 흡수선량을 모델식품의 위생화를 위한 살 균처리 선량으로 설정하였다.

Table 2. Effect of gamma irradiation on microbial population in the balanced nutritional formular

\begin{tabular}{lccccc}
\hline \multirow{2}{*}{$\begin{array}{c}\text { Irradiation } \\
\text { dose } \\
(\mathrm{kGy})\end{array}$} & $\begin{array}{c}\text { Total aerobic } \\
\text { bacteria }\end{array}$ & $\begin{array}{c}\text { Yeasts and } \\
\text { molds }\end{array}$ & $\begin{array}{c}\text { Bacillus } \\
\text { cereus }\end{array}$ & $\begin{array}{c}\text { Clostridium } \\
\text { perfringens }\end{array}$ & $\begin{array}{c}\text { Coliform } \\
\text { group }\end{array}$ \\
\hline 0 & $2.6 \pm 0.30^{1)}$ & $2.7 \pm 0.49$ & $2.5 \pm 1.31$ & $\mathrm{ND}^{2}$ & $2.6 \pm 0.01$ \\
2 & $\mathrm{ND}$ & $1.0 \pm 1.15$ & $\mathrm{ND}$ & $\mathrm{ND}$ & $\mathrm{ND}$ \\
4 & $\mathrm{ND}$ & $\mathrm{ND}$ & $\mathrm{ND}$ & $\mathrm{ND}$ & $\mathrm{ND}$ \\
6 & $\mathrm{ND}$ & $\mathrm{ND}$ & $\mathrm{ND}$ & $\mathrm{ND}$ & $\mathrm{ND}$ \\
8 & $\mathrm{ND}$ & $\mathrm{ND}$ & $\mathrm{ND}$ & $\mathrm{ND}$ & $\mathrm{ND}$ \\
10 & $\mathrm{ND}$ & $\mathrm{ND}$ & $\mathrm{ND}$ & $\mathrm{ND}$ & $\mathrm{ND}$ \\
\hline
\end{tabular}

\footnotetext{
${ }^{1)}$ Values are mean $\pm \mathrm{SD}(\mathrm{n}=5)$.
${ }^{2}$ Not detected within the detection limit $<101 \mathrm{CFU} / \mathrm{g}$
}

\section{복귀돌연변이 유발능 평가}

감마선 조사처리 $(4 \mathrm{kGy})$ 된 모델식품의 복귀돌연변이 유 발능 평가 결과를 Table 3 에 나타내었다. 시험에 사용된 모든 시험균주( $S$. Typhimurium TA 98, TA 100, TA 1535 , TA 1537)에 대하여 열수 및 메탄올 추출물 모두 대사활성계 존재 유무와 상관없이 음성대조군과 통계적으로 유의한 차이를 보이지 않았다. 반면 열수 추출물과 메탄올 추출물 각각에 대한 양성대조군의 경우 음성대조구와 유의적인 차이를 나타내었다 $(\mathrm{p}<0.05)$. 일반적으로 돌연변이원성의 판정은 음성대조군 복귀변이 집락 수의 2 배 이상인 경우를 양성으로 한다. 본 연구의 결과를 통해 $4 \mathrm{kGy}$ 의 흡수선량으 로 감마선 살균처리된 환자용 균형영양식의 열수 및 메탄올 추출물은 본 시험조건 하에서 사용한 모든 시험균주에 대하 여 복귀돌연변이를 유발하지 않는 것으로 판단하였다. 이 와 같은 결과는 감마선 조사된 닭고기가 복귀돌연변이를 유발하지 않는다는 Kwak 등(16)의 보고와 일치하였다.

\section{염색체 이상 유발능 평가}

감마선 조사처리된 모델식품의 염색체 이상 유발능 평가 결과를 Table 4에 나타내었다. 대사활성계 존재시의 양성대 조군으로 사용된 $\mathrm{B}[\mathrm{a}] \mathrm{P}$ 의 경우 77 개의 중기상 세포만이 정상을 나타내어 양성의 염색체 이상 유발능을 나타내었으 나, 열수 추출물과 메탄올 추출물 모두 시험 구간내에서 99개 이상의 중기상 세포가 정상으로 나타났다. 또한 대사 활성계 부재시의 양성대조군으로 사용된 $\mathrm{MMC}$ 의 경우 역 시 75개의 중기상 세포만이 정상으로 나타나 염색체 이상 양성을 나타내었으나, 시험물질 모두 농도와 상관없이 98 개 이상의 정상세포인 것으로 나타났다. $\mathrm{CHL}$ 세포의 경우 통상 자연발생의 염색체 이상을 가진 중기세포 출연율은 $3 \%$ 를 초과하는 일이 거의 없으므로 $5 \%$ 미만의 평균 이상 중기상 출연율을 음성으로 판정하며, $10 \%$ 이상의 염색체 이상이 나타날 경우 양성으로 판단한다(17). 따라서 본 연구 결과는 $4 \mathrm{kGy}$ 의 흡수선량으로 조사처리된 환자용 균형영 양식의 염색체 이상 유발성이 없다는 것을 의미하며, 30 $\mathrm{kGy}$ 로 감마선 조사처리된 돈육이 염색체 이상을 유발하지 않았다는 Kang 등(18)의 연구와도 일치하였다.

\section{소핵 유발능 평가}

감마선 조사처리된 모델식품의 소핵 유발능과 세포독성 평가 결과를 Table 5 에 나타내었다. 개체 당 2,000개의 다염 성적혈구(PCE)를 대상으로 소핵을 가지는 다염성적혈구 (MNPCE)의 발현빈도는 전 시험용량 단계를 걸쳐 음성대 조군(멸균 증류수)과 유의적인 차이를 나타내지 않았다. 한편 양성대조물질인 cyclophosphamide monohydrate 80 $\mathrm{mg} / \mathrm{kg}$ bw을 투여한 양성대조군에서는 음성대조군에 비해 소핵 발현빈도가 45 배 높게 나타나 유의적인 차이가 있었 다(p<0.05). 시험물질의 세포독성 지표인 총 적혈구 $(\mathrm{PCE}+$ 
Table 3. Salmonella Typhimurium reversion assay of gamma-irradiated balanced nutritional formular at 4 kGy

\begin{tabular}{|c|c|c|c|c|c|c|}
\hline \multirow{2}{*}{ Test compound ${ }^{1)}$} & \multirow{2}{*}{ Presence of S9 } & \multirow{2}{*}{$\begin{array}{c}\text { Conc. } \\
\text { ( } \mu \mathrm{g} / \text { plate) }\end{array}$} & \multicolumn{4}{|c|}{ No. of His+ revertant per plate } \\
\hline & & & TA 98 & TA 100 & TA 1535 & TA 1537 \\
\hline \multirow[t]{6}{*}{ Hot water extract } & + & 0 & $32 \pm 2^{2)}$ & $110 \pm 13$ & $13 \pm 4$ & $13 \pm 5$ \\
\hline & + & 321.5 & $34 \pm 5$ & $126 \pm 22$ & $11 \pm 2$ & $12 \pm 1$ \\
\hline & + & 625 & $35 \pm 5$ & $116 \pm 12$ & $12 \pm 4$ & $14 \pm 2$ \\
\hline & + & 1,250 & $36 \pm 3$ & $108 \pm 4$ & $9 \pm 2$ & $16 \pm 3$ \\
\hline & + & 2,500 & $30 \pm 3$ & $99 \pm 5$ & $10 \pm 1$ & $15 \pm 5$ \\
\hline & + & 5,000 & $33 \pm 4$ & $109 \pm 31$ & $16 \pm 2$ & $18 \pm 1$ \\
\hline \multirow[t]{6}{*}{ Methanol extract } & + & 0 & $32 \pm 3$ & $125 \pm 7$ & $14 \pm 2$ & $16 \pm 4$ \\
\hline & + & 321.5 & $31 \pm 4$ & $127 \pm 10$ & $11 \pm 3$ & $13 \pm 2$ \\
\hline & + & 625 & $37 \pm 3$ & $122 \pm 19$ & $13 \pm 1$ & $15 \pm 4$ \\
\hline & + & 1,250 & $33 \pm 4$ & $106 \pm 13$ & $12 \pm 4$ & $13 \pm 4$ \\
\hline & + & 2,500 & $32 \pm 3$ & $114 \pm 24$ & $15 \pm 3$ & $12 \pm 3$ \\
\hline & + & 5,000 & $30 \pm 3$ & $115 \pm 8$ & $13 \pm 3$ & $11 \pm 2$ \\
\hline $\mathrm{BP}$ & + & 1.0 & $492 \pm 41^{* 3)}$ & - & - & - \\
\hline 2-AA & + & 1.0 & -4) & $1,184 \pm 224^{*}$ & $257 \pm 44^{*}$ & $372 \pm 63^{*}$ \\
\hline \multirow[t]{6}{*}{ Hot water extract } & - & 0 & $37 \pm 2$ & $99 \pm 13$ & $15 \pm 2$ & $14 \pm 3$ \\
\hline & - & 321.5 & $40 \pm 2$ & $91 \pm 8$ & $13 \pm 3$ & $13 \pm 7$ \\
\hline & - & 625 & $38 \pm 4$ & $84 \pm 11$ & $14 \pm 3$ & $15 \pm 3$ \\
\hline & - & 1,250 & $34 \pm 5$ & $97 \pm 14$ & $10 \pm 2$ & $18 \pm 5$ \\
\hline & - & 2,500 & $36 \pm 4$ & $102 \pm 13$ & $11 \pm 3$ & $12 \pm 6$ \\
\hline & - & 5,000 & $35 \pm 3$ & $88 \pm 8$ & $12 \pm 3$ & $11 \pm 2$ \\
\hline \multirow[t]{6}{*}{ Methanol extract } & - & 0 & $38 \pm 4$ & $123 \pm 14$ & $15 \pm 3$ & $18 \pm 3$ \\
\hline & - & 321.5 & $34 \pm 4$ & $133 \pm 11$ & $12 \pm 3$ & $17 \pm 2$ \\
\hline & - & 625 & $33 \pm 4$ & $110 \pm 18$ & $14 \pm 4$ & $13 \pm 5$ \\
\hline & - & 1,250 & $35 \pm 5$ & $122 \pm 15$ & $16 \pm 3$ & $12 \pm 5$ \\
\hline & - & 2,500 & $36 \pm 3$ & $107 \pm 7$ & $13 \pm 2$ & $14 \pm 5$ \\
\hline & - & 5,000 & $37 \pm 3$ & $108 \pm 14$ & $11 \pm 4$ & $15 \pm 2$ \\
\hline SA & - & 5 & - & $1,213 \pm 189^{*}$ & $735 \pm 43^{*}$ & - \\
\hline $4 \mathrm{NQO}$ & - & 2 & $718 \pm 38^{*}$ & - & - & - \\
\hline ICR-191 & - & 2 & - & - & - & $862 \pm 36^{*}$ \\
\hline
\end{tabular}

${ }^{1)} \mathrm{BP}$, benzopyrene; 2-AA, 2-aminoanthracene; SA, Sodium azide; 4NQO, 4-nitroquinoline $N$-oxide; ICR-191, acridine mutagen ICR-191 were used as positive controls for the corresponding strains.

${ }^{2)}$ Each value represents revertant colonies per plate and is expressed in the mean $\pm \mathrm{SD}$ of three plates.

$\left.{ }^{3)}\right)^{*}$ Significantly different from the negative control $(p<0.05)$.

${ }^{4)}$ Not examined.

$\mathrm{NCE}$ ) 중 $\mathrm{PCE}$ 의 비율은 모든 용량처리군에서 $0.51 \%$ 수준인 음성대조군에 비해 유의적인 차이가 없었다. 소핵의 생성 은 마우스 골수 내에서 erythroblast가 최종 분열한 후 탈핵 과정을 거쳐 미성숙 적혈구인 PCE가 되는데, 이때 핵이 있는 erythrocyte 상태에서 시험물질이 돌연변이를 유발하 는 특성이 있다면 염색체 변이가 발생하여 더 이상 분화하 지 못하고 파편으로 남아 PCE 내에 존재할 때 발생된다. 소핵 시험의 양성 평가는 $\mathrm{PCE} / \mathrm{PCE}+\mathrm{NCE})$ 비율이 0.1 이상
인 경우 시험 수행이 적절한 것으로 하고 $\mathrm{MNPCE}$ 의 빈도가 통계학적으로 유의하며, 용량 의존적으로 증가하거나 하나 이상의 용량에서 재현성 있는 양성 반응을 나타낼 때 이루 어진다(19). 본 실험결과 $\mathrm{PCE} /(\mathrm{PCE}+\mathrm{NCE})$ 비율이 0.1 이상 이고 최대 실험 농도인 $2,000 \mathrm{mg} / \mathrm{kg} \mathrm{bw}$ 이하에서 모두 소핵 유발빈도가 음성대조군에 비해 유의적인 차이가 없었으므 로 $4 \mathrm{kGy}$ 의 흡수선량으로 감마선 조사처리된 환자용 균형 영양식은 소핵 유발능이 없는 것으로 판단하였으며, 
Table 4. Chromosomal aberration test on gamma-irradiated balanced nutritional formular at $4 \mathrm{kGy}$ using a lung cell line of Chinese hamster

\begin{tabular}{|c|c|c|c|c|c|c|c|c|c|c|}
\hline Test compound & Presence of S9 & $\begin{array}{c}\text { Conc. } \\
(\mu \mathrm{g} / \mathrm{mL})\end{array}$ & $\mathrm{G}^{1)}$ & $\mathrm{CD}$ & $\mathrm{CX}$ & $\mathrm{TD}$ & $\mathrm{TX}$ & Others & Nor & Total \\
\hline \multirow[t]{5}{*}{ Hot water extract } & + & 0 & 0 & 0 & 0 & 0 & 0 & 0 & 100 & 100 \\
\hline & + & 625 & 1 & 0 & 0 & 0 & 0 & 0 & 99 & 100 \\
\hline & + & 1,250 & 1 & 0 & 0 & 0 & 0 & 0 & 99 & 100 \\
\hline & + & 2,500 & 1 & 0 & 0 & 0 & 1 & 0 & 98 & 100 \\
\hline & + & 5,000 & 1 & 0 & 1 & 0 & 0 & 0 & 98 & 100 \\
\hline \multirow[t]{5}{*}{ Methanol extract } & + & 0 & 0 & 0 & 0 & 0 & 0 & 0 & 100 & 100 \\
\hline & + & 625 & 0 & 0 & 0 & 0 & 0 & 0 & 100 & 100 \\
\hline & + & 1,250 & 1 & 0 & 0 & 0 & 0 & 0 & 99 & 100 \\
\hline & + & 2,500 & 0 & 0 & 0 & 0 & 0 & 0 & 100 & 100 \\
\hline & + & 5,000 & 1 & 0 & 0 & 0 & 0 & 0 & 99 & 100 \\
\hline $\mathrm{BP}^{2)}$ & + & 20,000 & 2 & 0 & 3 & 4 & 14 & 0 & 77 & 100 \\
\hline \multirow[t]{5}{*}{ Hot water extract } & - & 0 & 0 & 0 & 0 & 0 & 0 & 0 & 100 & 100 \\
\hline & - & 625 & 2 & 0 & 0 & 0 & 0 & 0 & 98 & 100 \\
\hline & - & 1,250 & 0 & 0 & 0 & 0 & 0 & 1 & 99 & 100 \\
\hline & - & 2,500 & 0 & 0 & 0 & 0 & 0 & 0 & 100 & 100 \\
\hline & - & 5,000 & 0 & 0 & 0 & 0 & 1 & 0 & 99 & 100 \\
\hline \multirow[t]{5}{*}{ Methanol extract } & - & 0 & 0 & 0 & 0 & 0 & 0 & 0 & 100 & 100 \\
\hline & - & 625 & 1 & 0 & 1 & 0 & 0 & 0 & 98 & 100 \\
\hline & - & 1,250 & 0 & 0 & 0 & 0 & 0 & 0 & 100 & 100 \\
\hline & - & 2,500 & 0 & 0 & 1 & 0 & 0 & 0 & 99 & 100 \\
\hline & - & 5,000 & 1 & 0 & 0 & 0 & 0 & 0 & 99 & 100 \\
\hline $\mathrm{MMC}^{3)}$ & - & 100 & 7 & 0 & 10 & 1 & 7 & 0 & 75 & 100 \\
\hline
\end{tabular}

Number of findings of mean aberrant metaphases among 100 metaphases per culture.

${ }^{1)} \mathrm{G}$, gaps (chromatid type+chromosome type); CD, chromosome type deletions; CX, chromosome type exchanges; TD, chromatid type deletions; TX, chromatid type exchanges; Others, metaphases with more than 10 aberrations (including gaps) or with chromosomes fragmentation, Nor, normal.

${ }^{2)} \mathrm{BP}$, benzopyrene.

${ }^{3)} \mathrm{MMC}$, mitomycin $\mathrm{C}$.

Table 5. Frequency of micronuclei from marrow in mice treated with the balanced nutritional formular for patients gammairradiated at $4 \mathrm{kGy}$

\begin{tabular}{lccc}
\hline Test compound & $\begin{array}{c}\text { Dose } \\
(\mathrm{mg} / \mathrm{kg} \mathrm{bw})\end{array}$ & $\begin{array}{c}\text { MNPCE/PCE } \\
(\%)\end{array}$ & $\begin{array}{c}\text { PCE/(PCE+NCE }{ }^{3)} \\
(\%)\end{array}$ \\
\hline Distilled water & 0 & $0.04 \pm 0.04^{4)}$ & $0.51 \pm 4.34$ \\
\hline & 500 & $0.04 \pm 0.06$ & $0.49 \pm 2.70$ \\
Balanced nutritional & 1,000 & $0.04 \pm 0.06$ & $0.49 \pm 4.15$ \\
formular for patients & 2,000 & $0.04 \pm 0.02$ & $0.53 \pm 3.71$ \\
\hline $\mathrm{CPA}^{1)}$ & 80 & $1.80 \pm 0.24^{* 5)}$ & $0.29 \pm 2.39$ \\
\hline
\end{tabular}

${ }^{1)} \mathrm{CPA}$, cyclophosphamide monohydrate.

${ }^{2}$ MNPCE, micronucleated polychromatic erythrocyte; PCE, polychromatic erythrocyte.

${ }^{3)} \mathrm{NCE}$, normochromatic etythrocyte.

${ }^{4)}$ Each value represents the mean $\pm S D(n=5)$.

${ }^{5)^{*}}$ Significantly different from the negative control (distilled water) at $\mathrm{p}<0.05$.
$10 \mathrm{kGy}$ 이하로 감마선 조사처리한 과메기의 섭취가 마우스 골수 세포에 소핵을 유발하지 않는다는 Yook 등(20)의 결과 와 일치하였다.

\section{요 약}

본 연구는 환자용 균형영양식으로 제조하여 감마선 조사 처리를 통해 살균한 모델식품의 유전독성 여부를 평가하기 위해 수행되었다. $4 \mathrm{kGy}$ 이상의 흡수선량으로 감마선 조사 처리한 시료에서 생균수가 $1 \log \mathrm{CFU} / \mathrm{g}$ 의 검출한계 이하로 나타났기 때문에 살균을 위한 조사처리 선량으로 $4 \mathrm{kGy}$ 를 설정하였다. 복귀돌연변이 유발성 평가 결과, 모델식품의 열수 추출물과 메탄올 추출물은 처리한 용량과 대사활성계 존재 여부와는 상관없이 음성대조구(멸균증류수 또는 
DMSO)와 유사한 수준의 복귀돌연변이 발생빈도를 나타내 었다. 염색체 이상 시험에서 실험군들의 정상 염색체의 수 는 음성대조군과 유사하였으며, 용량 및 대사활성계에 대 한 비의존성을 나타내어 염색체 이상 유발능은 없는 것으로 판단하였다. 또한 최고 $2,000 \mathrm{mg} / \mathrm{kg}$ 체중의 농도로 모델식 품을 경구 투여한 마우스의 골수세포에서도 소핵 다염성적 혈구의 발생빈도는 음성대조군에 비해 유의적인 차이를 나타내지 않았다. 따라서 $4 \mathrm{kGy}$ 의 흡수선량으로 감마선 조사처리한 환자용 균형영양식은 본 실험 조건하에서 유전 독성을 나타내지 않는 것으로 사료된다.

\section{감사의 글}

본 연구는 2016년 정부(미래창조과학부)의 재원으로 한국 연구재단의 지원을 통해 수행되었으며(2012M2A2A6011320), 그 지원에 감사드립니다.

\section{References}

1. Ministry of Food and Drugs Safety (2016) 2015 production of food and food additives. Statistical yearbook of MFDS, MFDS 11-1470000-001922-10

2. Lee SY (2002) Manufacture processing of uncooked food on the market. Food Industry and Nutrition, 7, 11-15

3. Kim DJ, Ha SD, Ryu K, Park KH (2004) Hazard analysis and determination of CCPs for powdered raw grains and vegetables, Saengshik Korean J Food Sci Technol, 36, 1032-1040

4. Jung K, Song BS, Kim MJ, Moon BG, Go SM, Kim JK, Lee YJ, Park JH (2015) Effect of X-ray, gamma ray, and electron beam irradiation on the hygienic and physicochemical qualities of red pepper powder. LWT-Food Sci Technol, 63, 846-851

5. Bark SW, Kim KBWR, Kim MJ, Kang BK, Park WM, Kim BR, Ahn NK, Choi YU, Cho YJ, Ahn DH (2015) Effect of electrolyzed water and hot-air drying with UV for the reduction of microbial populations of Undaria pinnatifida. Microbiol Biotechnol Lett, 43, 38-44

6. Byun MW, Lee JW (2003) Application of irradiation technology for food safety and security. Food Science and Industry, 36, 25-41
7. Thayer DW (1990) Food irradiation: benefits and concerns. J Food Qual, 13, 147-169

8. Farkas J, Farkas CM (2011) History and future of food irradiation. Trends Food Sci Technol, 22, 121-126

9. Kim HC, Kim MR (1998) A study on the consumers' perception and acceptance toward food irradiation. Korean J Diet Cult, 13, 275-291

10. WHO (1981) Wholesomeness of irradiated food. Report of a joint FAO/IAEA/WHO expert committee, Technical Report Series-659

11. WHO (1997) High-dose irradiation: Wholesomeness of food irradiated with doses above $10 \mathrm{kGy}$. Report of a joint FAO/IAEA/WHO study group, WHO Technical Report Series-890

12. Kim HC, Kim MR (2003) Consumer attitudes towards irradiated foods. Fam Environ Res, 41, 119-130

13. Organization for Economic Cooperation and Development (1997) OECD guideline for testing of chemicals No 471: bacterial reverse mutation test. Paris, France

14. Organization for Economic Cooperation and Development (1997) OECD guideline for testing of chemicals No. 473: In vitro mammalian chromosome aberration test. Paris, France

15. Schmid W (1975) The micronucleus test. Mutat Res Environ Mutagen Relat Subj, 31, 9-15

16. Kwak HJ, Chung CK, Kang IJ (2001) Microbiological and genotoxicological safety of gamma-irradiated chicken. Korean J Food Cookery Sci, 17, 617-624

17. Wakata A, Sasaki MS (1987) Measurement of micronuclei by cytokinesis-block method in cultured Chinese hamster cells: comparison with types and rates of chromosome aberrations. Mutat Res Lett, 190, 51-57

18. Kang IJ, Park JHY, Kang YH, Lee HK, Byun MW (1999) Hygienic quality and genotoxicological safety of gamma irradiated pork. J Korean Soc Food Sci Nutr, 28, 1092-1098

19. Kim IB, Jeong JS, Yoon TJ, Kim JB (2013) Safety evaluation of Korean mistletoe extract. Korean J Food Nutr, 26, 383-390

20. Yook HS, Chung YJ, Song HP, Lee JW, Byun MW (2004) Genotoxicological safety of gamma-irradiated Kwamegi (semi-dried Colobabis seira). J Korean Soc Food Sci Nutr, 33, 182-192 